\title{
DREAMS FOR SALE \\ SOME OBSERVATIONS ON THE LAW OF IDEA SUBMISSIONS AND PROBLEMS ARISING THEREFROM
}

\author{
Harry R. Olsson, JR.**
}

I

INTRODUCTION

Begetting a child should bring little praise to a man for an effort which he would be glad to expend without acclaim. On the other hand, encouragement and aid are needed in raising the child to manhood, since in this respect, the parent's task is onerous, albeit somewhat pleasurable. So it is in the field of ideas; for an idea is readily conceived but brought to fruition only with sustained and toilsome effort. For the creative man, substantial reward should be postponed until after this toil has been expended and his work finished, for by his nature he finds such effort painful and is unwilling to persevere without the expectation of reward. Give him the pot at half-journey, and he will linger at the wayside.

Most of us half-absentmindedly assume ideas are desirable, but, of course, nothing is intrinsically good or bad about ideas per se, unless one is of the diminishing band that believes in inevitable progress. The last great war showed that many new ideas are better left unthought; and even though thought, unsaid; and even though said, unused. Critics say that certain radio and television programs confirm that these media are not exceptions to this observation. Probably no medium is.

Idea submission claims have been a real plague for many years, but, as an attorney writing about idea submitters and advertisers has observed, things have taken a turn for the worse in the past quarter century, as courts now have a tendency to allow recovery where they would not earlier have done so. ${ }^{1}$ Consequently, reward is being given prematurely to those who otherwise might turn their mere "ideas" into finished works, and the commercial users of ideas are exposed to danger by the law in some American jurisdictions if they depart from well-worn idea channels. The battlefield in these cases is generally that of the submitted idea for which the submitter later claims that compensation is due him as the result of a use allegedly made by the recipient of the idea.

Such a claim takes one of several guises: that the recipient expressly promised to pay the submitter if he used the idea; that he impliedly promised to pay if he used the idea; that the law imposes an obligation to pay on quasi-contractual unjust enrichment grounds if the idea is used; that the recipient took a property-the idea

* LL.B. I948, Columbia University. Member of the New York bar. Senior Attorney, National Broadcasting Company.

${ }^{1}$ Solinger, Idea Piracy Claims-or Advertiser, Bewarel, in Copyright Problems Analyzed 12I (1953). 
-belonging to the submitter and used it, thus committing a tort in the nature of a conversion; or, finally, that a fiduciary relationship was violated by the recipient.

Occasionally, the claim is made seriously that a statutory or common-law copyright infringement has been committed by the recipient; but copyright lawyers, as we shall see, have had little difficulty, except for a time in opportunity-rich California, in disposing of that contention. It is sometimes claimed that the act of use constitutes unfair competition; and in this area, all lawyers have difficulty, for unfair competition has been made the bridge between law and morality, and all sorts of baggage has been trundled across it since the historic International News Service v. Associated Press case. ${ }^{2}$

The law regarding idea submissions has been ably examined in print. ${ }^{3}$ Briefly, it has developed along the following lines:

a. Express Contract. The originator of an idea may protect it against the other party to an express contract. ${ }^{4}$ In Soule $v$. Bon $A m i^{5}$ however, the court held that consideration did not exist to support the defendant's promise where the plaintiff has promised to impart "valuable information" and what he imparted was not new and, therefore, not valuable. (He suggested Bon Ami raise its price to retailers.) So, too, in Masline v. New York, N.H. \& H.R. Co., ${ }^{6}$ where the plaintiff told the defendant he had "information of value" to defendant to communicate for consideration, and then suggested the defendant sell advertising space in its stations, depots, rights of way, cars, and fences. The court held that this information was not new and valuable, but that the offer and its acceptance presupposed the idea to be one not generally known. The court said, "When information is proffered as the consideration for a contract, it is necessarily implied, is indeed the essence of the proffer, that the information shall be new to the one to whom it is proffered." The last few words raise the interesting question whether attention should be focused on what is submitted or on the sophistication of the person to whom it is submitted. To let

248 U.S. 215 (19r8).

${ }^{3}$ Kaplan, Implied Contract and the Law of Literary Property, 42 CaltF. L. Rev. 28 (I954); Callmann, Unfair Competition in Ideas and Titles, 42 Calif. L. REv. 77 (1954); Note, 23 A.L.R.2d 244 (1952); Notes, 43 Connell L. Q. III (I957); 3 I id. at 382 (1946); I5 id. at 633 (1930); Note, I70 A.L.R. 449 (1947); 2 Rudolf Callanan, Unfair Competition and Trade-marks 849-56 (2d ed. I950); Note, 65 HaRv. L. REv. 673 (1952); Birmingham, A Critical Analysis of the Infringement of Ideas, in Copyright Law Smposium No. 5, at 107 (1954); Webster, Protecting Things Valuable-Ideas, in id. at 158; Solinger, supra note I; HarRy P. Warner, Radio and Television Rughts I073 (1953); Yankwich, Legal Protection of Ideas-A Judge's Approach, 43 VA. L. Rev. 375 (1957); Katz, The Publication of Intellectual Productions-A Common Sense Approach, 30 So. Calif. L. Rev. 48 (I956); Gershon, Contractual Protection for Literary or Dramatic Material-When, Where, and How Much?, 27 id. at 290 (1954); Nimmer, The Law of Ideas, 27 id. at 119.

'High v. Trade Union Courier Pub. Corp., 69 N.Y.S.2d 526 (Sup. Ct. 1946), aff'd, 275 App. Div. 803, 89. N.Y.S.2d 527 (Ist Dep't I949), appeal denied, 275' App. Div. 922, 90 N.Y.S.2d 68I (Ist Dep't 1949); Cole v. Lord, 262 App. Div. II6, 28 N.Y.S.2d 404 (Ist Dep't I94I); Spiselman v. Rabinowitz, 270 App. Div. 548, 61 N.Y.S.2d 138 (Ist Dep't 1946), appeal denied, 270 App. Div. 921, 62 N.Y.S.2d 608 (ist Dep't 1946).

201 App. Div. 794, I95 N.Y.S. 574 (2d Dep't 1922), aff'd, 235 N.Y. 609, I39 N.E. 734 (I922), rehearing denied, 236 N.Y. 555 (1923).

95 Conn. 702, 707, r12 Atl. 639, 640 (r921). 
"novelty" depend on whom the submitter selects would be rash and would subject the innocent and credulous to liability in cases where the worldly-wise go free.

b. Implied Contract. Williston has said that the elements necessary for an informal contract are the same whether the contract is express or implied by the facts. The character of the evidence by which the contract is established in each case is the distinguishing characteristic between the two. ${ }^{7}$ However, courts have required that the idea submitted be "novel" and "concrete" to support an implied contract. ${ }^{8}$ This requirement conforms to the interpretation of express contracts, though, of course, the parties to an express contract may bargain as they wish, and a peppercorn or an idea of common knowledge can be legally sufficient as consideration. ${ }^{9}$ To insist on novelty and concreteness has recently been termed "strange." Bo But how can it be strange? Implied contract has its roots in the behavior of reasonable men and what they have come to expect as normal in their society. It is unusual for any man to expect to be charged for any usual idea, and even more unusual for him to intend to pay for the use of what he already was free to use before the suggestion was made to him. The law in the implied contract area should provide as one condition of his liability that the idea should be as unusual as the promise to pay, and as ready for use in the form submitted as the money that was allegedly promised.

Whether custom in the industry will supply the lack of an understanding between the parties that the submitter will be employed in executing the idea or paid for its use has led to a divergence of views between New York and California. In New York, the Court of Appeals has held that proof of such custom will not be accepted in place of an understanding. ${ }^{11}$ In California, evidence of such custom is so. accepted. ${ }^{12}$

c. Quasi-Contract. There are apparently but two routes by which a plaintiff may recover on a quasi-contractual theory. The first-and more interesting, because so outrageous in light of the nature of ideas and of property-is that the idea, if novel and concrete, is property, and so the court will give judgment to the plaintiff against the defendant who used the idea and thereby was unjustly enriched at the plaintiff's expense. Belt v. Hamilton National Bank $k^{13}$ has much language in it which might support this reasoning; but the court there also found that the idea was disclosed in circumstances indicating that the parties contemplated compensation if the idea were used.

In a similar vein is John W. Shaw Advertising, Inc. v. Ford Motor Co., ${ }^{14}$ where

7 Williston on Contracts 8 (rev. ed. ig29).

${ }^{8}$ Hampton v. La Salle Hat Co., 88 F. Supp. 153 (S.D.N.Y. 1949); Stanley v. CBS, 35 Cal.2d 653, 22I P.2d 73 (I950).

${ }^{\circ}$ High Trade Union Courier Pub. Corp., 69 N.Y.S.2d 526 (Sup. Ct. 1946), afjd, 275 App. Div. 803,89 N.Y.S.2d 527 (Ist Dep't 1949), appeal denied, 275 App. Div. 922, 90 N.Y.S.2d 681 (Ist Dep't 1949).

${ }^{10}$ Note, 43 CoRnell L. Q. III, II3 (1957).

${ }^{11}$ Grombach v. Waring, 293 N.Y. 609, 59 N.E.2d 425 (1944).

${ }^{22}$ Kurian v. CBS, 40 Cal.2d 799, 256 P.2d 962 (1953).

${ }_{13}^{13}$ 108. F. Supp. 689 (D.D.C. 1952), affd, 210 F.2d 706 (D.C. Cir. 1953).

${ }^{14}$ I12 F. Supp. I2I (N.D. Ill. I953). 
the advertising idea was disclosed by the agency at the request of the companyIn both of the foregoing cases, however, it was unnecessary for the courts to rest their decisions on idea-is-property grounds, since the respective submitters had theimplied contract theory available to support their claims, and the judicial results. Of Galanis $v$. Procter \& Gamble, ${ }^{15}$ which deals with this general problem, more will be said hereafter.

The other type of quasi-contract claim as to which recovery has been sought successfully is presented where the plaintiff alleges he relied erroneously on what: he thought was a valid agreement for compensation and prays that he may recover the value of his services rendered by reason of this reliance, as was done in Matarese v. Moore-McCormack Lines, ${ }^{16}$ and Pillois v. Billingsley. ${ }^{17}$

In light of these quasi-contract cases, one writer has wondered why most advertisers continue to rely on a release form which makes the advertiser "the sole judge of the idea's novelty, usability, value; in fact, sole judge of everything."18 The answer, I believe, is that advertisers have justifiably relied on Davis v. General Foods Corps., ${ }^{18}$ where the understanding set forth in a written form provided that "the compensation, if any," to be paid would rest solely in the submittee's discretion. The "if any" language clearly showed that the possibility of no payment at all was a recognized possibility in the minds of the parties; and it is clear to this writer at least that no court would be warranted in substituting its judgment for that both of the submitterand of the submittee. The English cases relied on in Davis, holding it inconsistent to let a plaintiff recover after throwing himself on the defendant's mercy, make good sense.

Further, the Pillois and Matarese decisions do not shake Davis. In Pillois, the defendant had promised Pillois whatever the defendant in his sole discretion judged the services to be worth. There was no express recognition by the parties that Billingsley might judge the services to be of no value. The same is true of the Matarese case. In Davis, the submittee, by refusing to pay, had judged theidea to be of no value; and even Davis had from the first recognized this as a possibility. In Pillois and Matarese, the defendants had refused to perform their function of judgment-which was what the submitters had relied on in performing, and by the results of which they had agreed to be bound. The court in Davis would have had to decide two questions: whether to compensate the plaintiff, and, if so, how much. The courts in Pillois and Matarese had to decide only "how much," since the plaintiffs' agreed reliance on the defendants' judgments had been only regarding the amount of remuneration; and from the law's point of view, these defendants had refused to perform their duty to exercise judgment pursuant to a purported agreement on which plaintiffs had relied.

d. Equitable Relief. Under this heading, we might put rare, non-commercial situations similar to those already covered where the duty (a) not to use, or (b) not

\footnotetext{
${ }^{15} 153$ F. Supp. 34 (S.D.N.Y. 1957).

${ }^{27} 179$ F.2d 205 (2d Cir. 1950).

102 I F. Supp. 445 (S.D.N.Y. 1937).
}

${ }^{10} 158$ F.2d 63I (2d Cir. 1946).

${ }^{18}$ Solinger, supra note 1 , at I28. 
to disclose the idea, or (c) to compensate if it is used or disclosed arises neither from an express or implied contract nor a quasi-contract imposed by law, but where, instead, the duty arises out of a genuine fiduciary relationship created by law and/or contract. Even the introduction of "equitable" and "fiduciary" considerations has not, in New York, changed the courts' usual conclusion that the idea must be novel. ${ }^{20}$

II

\section{Some Recent Decisions}

Recently, the law has in no area shown less stability than in that relating to idea submissions. Last July, Galanis v. Procter \&. Gamble Corporation was decided by District Judge Dawson, who denied a motion by the defendant for summary judgment. Mrs. Galanis wrote to Procter \& Gamble on February II, 1952, to suggest "a soap I would call BLUE."21 The letter was answered on February 2I with a general letter which thanked Mrs. Galanis but pointed out some disadvantages of her proposal. ${ }^{22}$ The parties had no other oral or written correspondence; the idea

${ }^{20}$ Futter v. Paramount Pictures, 270 App. Div. 892, 69 N.Y.S.2s 438 (rst Dep't I947).

21 "To the President, Owner, or Manager

Procter and Gamble

Cincinnati, Ohio

Dear Sir:

I have an idea I would like to sell to you about a new kind of laundry soap that would be a sensation and a great god-send to many housewives on washday! A soap I would call BLUE. A new kind of soap with blue added into it. I have tried and tested a granulated soap with the addition of pulverized blue (bluing) into it and it works wonders.

It washes clothes and doesn't leave a streak of blue in this. I put the amount of soap I ordinarily use for my wash right into my washing machine (I have a Bendix). It washes, and rinses three times automatically and then damp dries them. Of course the soap I put in has the blue granules in it, all pulverized blue. It is a great time saver. You don't have to wait around and prepare your blue with water to get the right amount in it or you don't have to buy the ready-made bluing in a bottle. You have to also add water to that. It takes time. Lots of trouble too. Sometimes you don't have any blue in the house and you wash without it. Or if you do have the blue, just look at all the trouble it takes on washday to be adding the blue, either before the wash or wait until your washing starts the rinsing period.

I tell you, I wouldn't do without it. I prepare my blue (pulverize it) and add it to my soap and keep it in a jar. I don't have time to be bothered with it. Lots of other women are the same about it. I use different soaps sometimes. At first I used Rinso, because my washing machine company advised me to. But it didn't get my clothes white. Then, when your Tide came in, I started using that. I can't do without it. It is a wonderful soap. That is the soap I put the blue in. You should try it, or you may be able to manufacture a soap with the blue in it into granules.

It would be something different. Of course, this would just be a laundry soap for clothes. It wouldn't be used for dishes. So we still have to have our regular soap besides.

Nearly every woman uses blue when- they wash clothes. Those who don't, do not have the blue handy or can't be bothered with it. So if you have a soap all ready for us, our troubles would be over. I would like to know what you think of my idea.

With automatic washing machines you add blue together with your soap when washing. You need not wait until you rinse to add it. That is why I say to combine the two.

Please let me hear from you."

32 "Mrs. Constantine N. Galanis

Route I, Box 273

Annandale, Virginia

Dear Mrs. Galanis:

You were very friendly and thoughtful to write us about the possibility of bringing out a combination bluing and washing product. 
letter was unsolicited. The plaintiff concluded and alleged that she had offered to sell to Procter \& Gamble an idea originated by her and put into concrete form, which included a specific name for the product and various advertising phrases and suggestions to promote the new soap, and that, in I953, her idea was put to use by them without compensation to her. All of this, in her view, constituted an appropriation of her idea, in which she had a property right, and so gave rise to an implied contract which was breached by Procter \& Gamble's failure to compensate her.

The defendant moved for summary judgment on a single ground-that the unsolicited mailed-in disclosure of an idea constituted a forfeiture and/or dedication of the idea. Before getting into his discussion of the questions raised, Judge Dawson noted that the plaintiff claimed she had suggested a specific name for the product, but he added that examination of her letter did not show it. It is difficult to understand what construction the judge placed on "a soap I would call BLUE," and this difficulty probably led the defendant's attorneys to expect the best as they read the opinion. The judge held:

I. the submission was unsolicited, and there was no fiduciary relationship between the parties;

2. the idea was not protected by patent, copyright, or contract;

3. it was only a suggestion for putting two well-known products together and selling them as one; and

4. a mere idea is not property, and any right to its exclusive use is lost by voluntary disclosure.

At this point in their readings of the opinion, the defendant's attorneys must have been ready for a vacation in Florida (attorneys who defend idea cases for defendants steer clear of California). Their natural expectations were, however, to be disappointed. For, said the court, it has been recognized in certain cases that even if plaintiff has no property right in an idea, and even though no contract for the sale or use of such idea has been established, nevertheless, the defendant may be held liable in quantum meruit on the theory of unjust enrichment, where defendant utilized a concrete and novel idea submitted by the plaintiff.

To support this view of the law, Judge Dawson referred surprised readers of the opinion to Matarese v. Moore-McCormack Lines, Inc., and Miller v. Schloss. ${ }^{23}$ The latter nonidea opinion treats excellently the general nature of quantum meruit liability; but the former case offers small support to the Galanis decision. Indeed, Matarese is, in essence, an employer-employee, solicitation, encouragement, promise

\footnotetext{
We have considered such a product many times in the past but up to now, have always decided against it. The principal objection that we have had is that such a product would have fairly limited uses. It would be excellent for the regular laundry but many people do not like to use a blue wash product for dishes, for colored fabrics or for lingerie.

We have been approaching this problem from a slightly different angle in using fluorescent or 'white' dyes in our products like Tide, Duz and Oxydol. These products add to the whiteness of the fabrics and really make the use of bluing unnecessary.

We appreciate your interest very much and want to thank you again for taking the time to write us." ${ }_{23} 218$ N.Y. 400,113 N.E. 337 (1916).
} 
of compensation, and acceptance case. Plaintiff was an employee whose scope of employment assuredly did not include the subject matter of the lawsuit, and the company -officials actively encouraged and participated in the acts which constituted the disclosure and submission. Indeed, Judge Clark, who delivered the Matarese opinion, expressly stated there in discussing the leading case of Bristol v. Equitable Life Assur. Soc. of New York, ${ }^{24}$ that: ${ }^{25}$

Courts have justly been assiduous in defeating attempts to delve into the pockets of business firms through spurious claims for compensation for the use of ideas. Thus to be rejected are attempts made by telephoning or writing vague general ideas to business corporations and then seizing upon some later general similarity between their products and the notions propounded as a basis for damages. See Grombach Productions v. Waring, 293 N.Y. 609, 59 N.E.2d 425; Lueddecke v. Chevrolet Motors Co., 8 Cir. 70 F.2d 345. Such schemes are quite different from the situation envisaged in the Bristol case, supra, and that at bar. Here the relationship between the parties before and after the disclosure, the seeking of disclosure by Furey [Furey was the defendant's agent in charge of the pier on which Furey worked at the time of the submission. He later was promoted from Stevedore Superintendent to Chief of Operations, an executive position with wide powers sufficiently "high to justify his accepting for the company benefits of the more efficient stevedoring" suggested and put into operation by the plaintiff], Furey's promise of compensation, the specific character, novelty, and patentability of plaintiff's invention, the subsequent use made of it by defendants, and the lack of compensation given the plaintiff-all indicate that the application of the principle of injust enrichment is required. Miller v. Schloss, supra.

Actually, the Galanis situation fits perfectly into the principle stated in the Bristol case by the court of appeals, that: ${ }^{26}$

Without denying that there may be property in an idea, or trade secret or system, it is obvious that its originator or proprietor must himself protect it from escape or disclosure. If it cannot be sold or negotiated or used without a disclosure, it would seem proper that some contract should guard or regulate the disclosure, otherwise it must follow the law of ideas and become the acquisition of whoever receives it.

In summing up, the Galanis court, citing Belt v. Hamilton National Bank, a District of Columbia case, stated that for the plaintiff to recover it would be "necessary for her to establish (I) that the idea was novel, (2) that the idea was concrete, and (3) that the idea was actually appropriated by the defendant in the development of a product which it put out."27 The letter of Mrs. Galanis was sent from Virginia to Ohio; the defendant's from Ohio to Virginia; and the suit was brought in New York. The District of Columbia had nothing to do with the lawsuit and no explanation is given for the apparent reliance on a precedent from that jurisdiction.

${ }^{26} 132$ N.Y. 264,30 N.E. 506 (1892). The principles of Bristol were recently reaffirmed in New York by Carneval v. William Morris Agency, I24 N.Y.S.2d 3 I9 (Sup. Ct. 1953), aff'd, 284 App. Div. I04I, I37 N.Y.S.2d 612 (Ist Dep't 1954), appeal and reargument denied, 285 App. Div. 87x, 30 B N.Y. T052 (1955).

${ }^{25}$ I58 F.2d 631, at 634 .

${ }^{28}{ }_{132}$ N.Y. at 265,30 N.E. at 507.

${ }^{27}$ I53 F. Supp. 34 , at 38 . 
On the other hand, not a single Ohio or Virginia case is cited in the entire Galanis opinion for any proposition whatsoever.

The court concludes it has considerable doubt the plaintiff will be able to sustain her burden of proof. It is submitted the plaintiff should never as a matter of law get the chance to do so. Yet, a motion for reargument has now been denied, the court saying that full consideration had previously been given all the issues. Thus, the Galanis case will apparently proceed to trial.

In Belt v. Hamilton National Bank, ${ }^{28}$ the jury had found a verdict for the plaintiff of $\$ 3,300$. The plaintiff's evidence was that-after making the same suggestion to several others, including the assistant superintendent of public schools-he had suggested to defendant that it sponsor a series of half-hour weekly radio programs with talent to be selected by auditions in the high schools. An outline of the format provided that school atmosphere would be retained by referring to the show as a class, to the acts as class assignments, and to the action as class recitations. Each week, a different school and its glee club would be featured. If desired, Belt would conduct the auditions, production, and presentation. It was proposed there be a minimum of conversation and introductions, the programs being devoted to a "fast moving, first rate, entertaining show," with no commercials, except that the sponsor would be given brief credit at the beginning and end of the broadcast. Following this suggestion, Belt and the bank entered into an agreement under which Belt was to be paid $\$ 25.00$ weekly and was to make the necessary arrangements with the schools for auditions and transcriptions. If the bank approved the transcribed programs and caused them to be broadcast, a revised agreement covering the plaintiff's duties and pay was to be made. The school authorities at first refused the necessary approval, and, in accordance with its right under the agreement, the bank cancelled its contract with Belt. Some time later, the Board of Education advised the bank of its willingness to approve such a program, and for a little over a year, broadcasts were made with the assistance of a person other than Belt. Judge Holtzoff, in denying defendant's motion for judgment notwithstanding the verdict, observed that at common law no "property right existed in an idea" and then noted that one of the law's basic characteristics is its capacity for growth and flexibility. He does not tell us how the law grew so as to comprehend property right in an idea, but he does conclude that Belt got one. It must be observed that growth, in itself, is not necessarily a desirable thing and that when growth takes place, it ought to be a beneficial direction. Otherwise, the growth prevents the very progress that judges so often dwell upon when they do not like the precedents. ${ }^{29}$

During the course of the opinion, Judge Holtzoff stated that "the law now gives effect to a property right in an idea even though the idea may be neither patentable nor subject to copyright," and the terms "property right," "limited property right," "qualified property right," "property right subject to sale," and "owner of an idea"

${ }^{28}$ I08 F. Supp. 689 (D.D.C. I952).

${ }^{30}$ Holmes v. Hurst, I74 U. S. 82 (1889); Eichel v. Marcin, 24 I Fed. 404 (S.D.N.Y. r9I3). 
are used without any real analysis of what they mean. One consequence of having a property right or being an owner has always been the power to exclude the whole world from the use of the thing owned. It is manifestly absurd to suppose that Judge Holtzoff meant to suggest that Belt could exclude the world from the use of this idea. To say that rights against the bank arose in Belt out of a relationship that he had with the bank, the relationship being in part confidential and in part fiduciary, might enable the court to reach the same result, without suggesting that Belt enjoyed an idea monopoly.

The Circuit Court committed the same sort of judicial error. Its opinion contains statements like "nor had the idea become public property on disclosure to the bank." 30 This statement is utter nonsense if it implies that a change might have taken place as to whether or not the idea was public property. It makes good sense only if it states the obvious fact that the idea was not property before disclosure nor afterwards either. The point is that to play with the word and concept "property" in this context is meaningless, unnecessary, and confusing.

Other courts have said that a novel and concrete idea prior to disclosure is the property of the originator. However, "property" serves no purpose if the idea has not been disclosed; it certainly is not property in the sense that others can be lawfully prevented from using the novel idea. Lest this seem like cavilling, consider some possible results of using the label property as to an idea. Such an idea may then serve as the basis for a quasi-contractual recovery or for a suit based on infringement of a property right.

The lengthiest and farthest ranging opinions in the country on idea submissions have come from the Supreme Court of California. In Stanley v. Columbia Broadcasting System ${ }^{31}$ concerning the program "Hollywood Preview," the plaintiff sought successfully to recover in implied contract from the defendant for a radio program format the plaintiff claimed to have originated. The court conventionally ruled that, for the plaintiff to recover, his idea had to be novel and reduced to concrete form prior to its disclosure and then revealed under circumstances indicating that compensation was expected if the idea was used. In Golding $v . R K O^{32}$ the court, in an action for infringement of literary property, held that California copyright law ${ }^{33}$ protected the basic plot of a paranoic ship's captain obsessed by his

${ }^{30}$ Hamilton Nat. Bank v. Belt, 210 F.2d 706, 710 (D.C. Cir. 1953).

${ }^{31} 35$ Cal.2d 653, 221 P.2d 73 (1950).

${ }^{32} 35$ Cal.2d 690, 221 P.2d 95 (x950).

${ }^{38}$ Although the majority opinion is lengthy, there is no quotation in it of section 980 of the Civil Code. In his dissenting opinion, Judge Traynor refers to it as it read following amendment in 1947: "The author or proprietor of any composition in letters or art has an exclusive ownership in the representation or expression thereof as against all persons except one who originally and independently creates the same or a similar composition." When the Golding suit was brought, section 980 read: "The author of any product of the mind, whether it is an invention, or a composition in letters or art, or a design, with or without delineation, or other graphical representation, has an exclusive ownership therein, and in the representation or expression thereof, which continues so long as the product and the representations or expressions thereof made by him remain in his possession." Justice Edmonds who delivered the majority opinion in Golding and also in Weitzenkorn v. Lesser, 40 Cal.2d 778, 256 P.2d 947 (1953), observed in the latter case that in Golding, the court had relied on the earlier wording of the section and so 
authority, engaged by an opponent aboard his ship, and defeated by that opponent with resultant mental collapse. (The action did not concern The Caine Mutiny.)

In a pair of almost equally-lengthy opinions, the same court, in I953, decided the cases of Weitzenkorn $v$. Lesser ${ }^{34}$ and Kurlan v. Columbia Broadcasting System. ${ }^{35}$ The plaintiff in the first case alleged three causes of action arising out of the claimed piracy of a Tarzan adventure. The first count pleaded an express contract; the second count, quantum valebant; the third count, copyright infringement. The court held that the first count was sufficient because Weitzenkorn "might be able to introduce evidence showing that the parties entered into an express contract whereby Lesser and Lesser Productions agreed to pay for her production regardless of its protectibility and no matter how slight or commonplace the portion which they used"; such evidence would present a question of fact for the jury. Further, no question of protectibility need be considered by the court in ruling on the demurrer, for the disclosure itself could be sufficient consideration to support the promise.

The court's opinion regarding the second count is also interesting. It said that, on this common count, recovery could be had in proper circumstances for either a contract implied in fact or a quasi-contract. ${ }^{36}$ The court went on to comment that the conduct of the parties could support a recovery on the former ground. However, only a property right wrongfully used by the defendant could support a quasicontractual recovery (apparently ruling out in California the possibility of recovering on this theory when there have been services rendered pursuant to reliance on what was erroneously thought to be a valid contract) ${ }^{37}$ Consequently, the proof necessary to support a recovery on this theory is the same as that necessary to support a recovery on the third pleaded count, copyright infringement. Since the court concluded from the pleadings that no property belonging to Weitzenkorn had been used, the demurrer to the third count was held sufficient. The second count was allowed to stand because of the implied contract possibility, but the court noted that no recovery could be had thereunder on the quasi-contract theory.

In Kurlan v. CBS, allegations that the defendants had utilized a radio script and program format of "My Sister Eileen" were the basis for no fewer than five causes of action: the first in express contract; the second and third in quantum valebant; the fourth on a contract implied from trade customs, practices, and usages; and the fifth cause being one in which it was alleged that the defendants appropriated by certain conduct "the rights ... to which" plaintiff was "exclusively entitled," and

\footnotetext{
extended protection to "the basic dramatic core" of Golding's play and that California, following the amendment, accepted the traditional protectible property of common-law copyright.

as 40 Cal.2d 778, 256 P.2d 947 (1953).

${ }^{36}{ }_{40}$ Cal.2d 799, 256 P.2d 962 (1953).

so The term "contract implied in law" is avoided and "quasi contract" preferred herein for the reason that the latter term is less apt to confuse.

${ }^{97}$ Contrast Matarese v. Moore-MrCormack Lines, I58 F.2d 631 (2d Cir. 1946).
} 
that they destroyed the value of his "personal property."38 The court held proper the overruling of demurrers to all causes of action. It reiterated what it had said about the quasi-contractual cause of action's relationship to copyright and that express contract and implied contract had been put on the same footing except as to the evidence necessary to sustain the making of the agreement.

Perhaps Desny $v$. Wilder ${ }^{30}$ will signal the end of very long idea-submission opinions from the California Supreme Court. Only two judges delivered opinions, as opposed to three in Stanley, three in Weitzenkorn, and four in Kurlan, but the court leaves no stone unturned. In his separate concurring-only-in-result opinion, Justice Carter is heartily critical of "the lengthy discussion of numerous principles of law wholly inapplicable and unnecessary to a determination of this matter." $\mathrm{He}$ adds that such useless, although learned, discussions must later be distinguished, dissented from, and finally overruled by subsequent decisions. ${ }^{40}$ The court, among other things, examined the factual substance of the record, the nature of the judgment appealed from, and the rules governing its consideration of that judgment, and then discussed the law of ideas, the law of literary property, the law of contract as it relates to transactions concerning ideas and literary property, with definitive recognition of the somewhat differing situations to which, as descriptive of the "contract" or obligation, some authorities apply the terms "express," "inferred," "implied in fact," "implied in law," or "quasi-contractual," and "the significance of the subjective and objective tests in determining contractual existence under the several possibly pertinent theories." ${ }^{41}$

The defendant Wilder was employed by the defendant Paramount "either as a writer, producer or director or as a combination thereof." In 1949, the plaintiff phoned Wilder's office, spoke to his secretary, and said he wanted to see Wilder. At her insistence that he give his purpose, the plaintiff told her a "fantastic unusual story" about Floyd Collins, who was trapped in a cave more than eighty feet deep. He explained that the picture had never been made with a cave background before and asked to send it to Wilder. When the secretary learned it was sixty-five pages long, she said her boss would not read it and the story would have to be sent to the script department first, so that, if thought by them to be "fantastic and wonderful," it could be condensed to three or four pages for the producers and directors to see it. Apparently in the fear that some of the fantasy and wonder would be lost to the story, Desny protested that he wanted to do the condensing himself and the secretary suggested he do so. Two days later, Desny called again after he had prepared a "three or four page" outline of the story and told her it was ready. She asked him to read it to her over the telephone so that she could take it down in shorthand, and he did so. She remarked that she liked the story, would talk it over with

\footnotetext{
${ }^{38}$ Solinger called this "a cause of action in the nature of copyright infringement." See Solinger, stipra note $\mathrm{I}$, at 137 . Perhaps the attorneys for Kurlan felt the way the wind was blowing in California and wanted to avoid what might be called the "label handicap" of copyright.

${ }_{30}^{36}$ Cal.2d 715, 299 P.2d 257 (1956). $\quad{ }_{40}^{40}$ Cal.2d at 752, 299 P.2d at 279.

$146 \mathrm{Cal} .2 \mathrm{~d}$ at 724,299 P.2d at 260 .
} 
Wilder, and then would let Desny know the result. Desny explained to the secretary that defendants could use the story only if they paid him its reasonable value, whereupon she said that if Billy Wilder of Paramount uses the story "naturally we will pay you for it." Desny did not remember ${ }^{42}$ whether, during the first conversation, anything was said about his purpose of selling the story to the defendants. At no time did he speak to Wilder. Plaintiff's only subsequent contact with the secretary was in 1950, when he called to protest the alleged use of his "composition and idea in a photoplay produced and exhibited by the defendants."

For the purpose of argument, Desny conceded that his synopsis was not sufficiently original or unique to provide the basis for a recovery under infringement law, and he admitted that he got the central idea for his story from the widely-publicized. Floyd Collins incident in the 1920's. However, he argued that the grant of a summary judgment had the result of denying him the right to prove that his idea or synopsis was the subject of a contract whereby defendants promised to pay him if they used it.

The California Supreme Court's detailed discussion of the law pertaining to ideas was presumably intended to provide definitive guidance for future litigants in a jurisdiction whose tribunals naturally tend to hear a substantial share of the entertainment industry's cases. At the outset, the majority emphasizes that ideas, being "as free as the air and as speech and the senses," are not usually regarded as property. Reliance is placed in the principle enunciated in Justice Brandeis' dissent in International News Service v. Associated Press, that an "essential element of individual property is the legal right to exclude others from enjoying it." Property inheres only in an "expression" of the ideas.

Nonetheless, the court, adopting the view of Justice Traynor's dissent in Stanley v. $C B S$, reasons that disclosure of an idea can be consideration for a promise to pay even though the idea disclosed may be widely known and generally understood. Analogizing the position of free-lance writers to that of a lawyer or doctor who may chance to render services without a prior express contract, the majority states that one who conveys a valuable idea to a producer who commercially solicits the service or who voluntarily accepts it knowing that it is tendered for a price should likewise be entitled to recover.

The court then turns to a discussion of contractual law and distinctions between express, implied, and quasi contracts, with particular reference to some of the definitions in the California Code. Although conveyance of an undisclosed idea can constitute valuable consideration if bargained for, the majority finds that once an idea is disclosed without such a bargain, it then becomes the property of the proposed purchaser to use as he sees fit, and without remuneration if he so chooses. However, should the producer be a person of good heart and, after disclosure of the idea, promise to pay therefor, that promise is legally enforceable.

\footnotetext{
's Desny's deposition had been taken, and it was treated as an affidavit in opposition to defendants'
} motion for summary judgment. 
One thing is made clear by the court. If a producer has an opportunity to reject an idea that is submitted to him, but instead voluntarily accepts its disclosure and then finds it valuable and uses it, the California courts will either find a promise to pay or imply one. Obversely, absent an opportunity to reject, the producer will not be bound to pay. The idea man who blurts out his idea without having first made his bargain has no one but himself to blame for the loss of his bargaining power.

From the evidence before it, the court concluded that Desny had not shown that any contract was ever made to pay for his idea. Therefore, absent the dictation of the synopsis to defendant Wilder's secretary, Paramount Pictures would have been free to have had its writers research the Floyd Collins incident and prepare a script to be based thereon. However, since Desny's synopsis might have been used by the defendants, the court found it necessary to go into the law pertaining to literary property, and, in the light of that law, determined to deny the motion for summary judgment.

Since the plaintiff had no statutory copyright, his claim as to the synopsis necessarily must rest in a common law property right or in contract. Desny had elected to rest his argument solely on a contract theory, but there is at least some intimation in the majority's opinion that they might have upheld a common-law property right if they had been confronted with that issue.

The defendants had raised an issue of authority by submission of affidavits that neither Wilder nor Wilder's secretary had authority to negotiate contracts for the purchase of scripts. However, in this respect, the court noted: ${ }^{43}$

Factually it would be inconsistent, and legally it would be untenable, for the defendant corporations to deny that Paramount's employes, Wilder and the secretary, had authority to negotiate contracts for the purchase of literary material and at the same time to permit them to act as agents for the procurement of material offered for sale, and to use the material so acquired while disavowing the authority of the agents.

-....

If the secretary had authority to receive and transmit messages to her employer-such as messages offering to sell a story embodying a writer's idea for a photoplay-and to take down in shorthand for transmission to her employer the script of a synopsis, she also necessarily had authority to receive and transmit the conditions and terms of the offer.

In the court's discussion of the secretary's authority, the offer by Desny is likened to an offer of office supplies that might be left with the same secretary. However, this parallel is somewhat misleading. Suppose that a salesman left with the secretary a nonpatented, well-known stapler to try and possibly buy. Would a jury later be permitted to find, in the absence of unequivocal language, that a later use of another different stapler constituted acceptance by the corporation of an implied offer from the salesman to sell the idea of using a stapler?

'This is the flaw in Desny. What should have been a straight literary property and contract case was treated not only as that, but also as an idea case. Nothing " at Cal.2d at 745, 299 P.2d at 274 . 
was alleged to support the conclusion that the parties were dealing about an idea. Desny attempted to sell a sixty-five page story or a synopsis of it. Not a word was said about the idea of producing a picture based on the Floyd Collins incident. If the defendants accepted the offer, their acceptance could reasonably be only of what they would reasonably understand the offer to be. The true rule requires that anything so extraordinary as an idea offer must be made crystal-clear for what it is to the offeree. In the court's lawyer and doctor illustrations, the only acceptances reasonably construable on the parts of the client and patient would be of the services, and most certainly not of the ideas the lawyer and doctor used.

In Justice Carter's concurring-in-result-only opinion, he makes several points regarding the law which should give us pause. ${ }^{44}$ He says: ${ }^{45}$

"a. The seller of this type of merchandise stands in an inferior bargaining position. Comment: If this be so, is it the function of the law to put the parties into an equal bargaining position? The idea salesman has little, if anything, of value to sell; that is why he has a poor bargaining position. The author with a good, completely-finished work has a fine bargaining position.

b. Producers are hard to reach. Comment: Only producers with money are hard to reach. But seriously, the Desny sort of decision will not encourage them to make idea submitters more welcome. It might well be their attorneys have now advised them to make their secretaries harder to reach, too.

c. No purchaser is going to buy a "pig in a poke." Comment: Very true. How then, in the absence of clear words to the contrary, can a court find that he impliedly agreed to pay for the idea if he used it? To say that he willingly accepted the idea is no answer in Desny. It is only reasonable to say that the composition was accepted if it is reasonable to say that Wilder et al. accepted anything. Incidentally, how in the world can a submittee, by his conduct, indicate his willingness to pay for the use of a commonplace idea? It is almost equally inconceivable that the submittee by his conduct would indicate that the "pig in a poke" in his head was a commonplace animal.

d. When the writer has conveyed his idea to such a prospective purchaser, he has lost the result of his labor and there is no way he can protect himself. Comment: This same argument (regarding loss of common-law copyright on publication) has been made as effectively as it can be by Judge Aston, in the great case of Millar v. Taylor, 4 Burr. 2302, 2342, 98 Eng. Rep. 201, 221 (K.B. 1769), in part as follows: "Now, without publication, 'tis useless to the owner, because without profit; and property without the power of use and disposal is an empty sound. In that state, 'tis lost to the society in point of improvement, as well as to the author in point of interest. Publication, therefore, is the necessary act and only means to render this confessed property useful to mankind and profitable to the owner; in this they are jointly concerned. Now, to construe this only and necessary act to make the work useful and profitable, to be destructive at once of the author's confessed original property, against his expressed will' seems to be quite harsh and unreasonable. ..." See also Eaton S. Drone, The Law of Property in Intellecrual Productions I et seq. (1879). Yet, both the House of Lords, in Donaldson v. Becket, 2 Bro. P.C. I29, I Eng. Rep. 837 (H.L. 1774), and the United States Supreme Court, in Wheaton v. Peters, 33 U.S. (8 Pet.) 591 (1834), held that the statute of 8 ANNE c. 19 (1710) took away the common-law right after publication. The same judicial policy that led these judges, in the face of an act that was, to say the least, unclear, to hold that authors lost the common-law right after publication by virtue of the act has led judges to hold an idea is lost on disclosure unprotected by contract. Obviously, behind both historic judicial decisions is the weighty public policy against a form of thought control in each instance. In copyright, the area controlled is relatively narrow, and it takes more-publication-to result in forfeiture; in idea, the idea controlled is much greater, and it takes less-disclosure-to result in similar forfeiture. It is unwise, it is submitted, for judges to undermine these historic policies. Of course, the term "thought control" really means "expression of thought control."

e. This case is a beautiful example of the practical difficulties besetting a writer with something to sell -he is not permitted even to see the secretary in person-he must convey to her over the telephone the result of his efforts. Comment: If by "something" is meant the literary composition, his copyright protection (all that the ancient wisdom of the law has afforded him) is not lost. If his basic idea is meant, he had nothing to sell in the first place, he could convey no exclusive rights in it; Paramount's competitors would remain able to use the idea as freely after the conveyance as they were before it.

In this particular instance, the NBC Network broadcast a-television'play telling the Floyd Collins 
It seems to me most obvious that a seller of literary work would not disclose his ideas incorporated in his work to a prospective purchaser of the same without an implied understanding on the part of both that such an idea, if used by the one to whom it was disclosed, would be paid for by the one in a position to use the literary work.

It is submitted that Justice Carter, too, has misstated the reasonable intention of the parties. Grant that the would-be seller has a property in his literary work. It is this property in a specific document, and this only, that he reasonably can expect to sell. While he may hope to be in a position to prevent the prospective purchaser from ever thereafter using any of the multitude of ideas implicit in his written production, surely he should have no reasonable expectation of doing so. In the absence of some clearly-expressed, soundly-proven indication to the contrary, is it reasonable to suppose that a prospective purchaser who talks with the "idea man" expects that, as a result of the conversation, he will be unable to use ideas he was perfectly free to use before it? Perhaps it will be replied that the submittee would not be free after such access to use the copyright protected portions of any literary work he was shown. But the forbidden areas in the copyright situation are of enormously narrower scope than in the idea situation. Who can tell whether the submittee in a case like Desny could ever again, without grave fear, do any story about Floyd Collins? Or a man trapped underground in a cave? Or about Crystal Cave? Or about Kentucky? If the literary work is the subject of federal copyright protection, the maximum period of such protection is fifty-six years. Justice Carter, in the final words of his opinion, brings into the stark light one of the nightmares of this field and confirms our worst fears, for he says: ${ }^{48}$

It appears to me that the positions occupied by the parties should be sufficient to raise the inference that if the literary work is used by the prospective buyer, compensation would be paid therefor regardless of how much time the buyer takes to decide whether he will use it.

In Glane v. General Mills, Inc., ${ }^{47}$ the plaintiffs, who had been employed by the defendant prior to 1945, wrote their former employer that they were working on an idea for a packaged kit designed for youngsters, which would contain a cooking apron, cooking utensils, a recipe book, sample packages of defendant's products, and perhaps a club membership card which could be sent to Martha Meade or Betty Crocker. The letter added, "If you are interested in this idea, we would naturally expect to have a conference with you personally on this matter. We would be glad to send you a sample kit which we are now working up if you would like to have us

story without permission from Desny, Paramount, Wilder, or Wilder's secretary, on the "Robert Montgomery Presents" program of January 2r, I957. Desny, as the court held, was as well off talking to the secretary as if he had talked to Wilder himself; perhaps he was better off-Wilder would more likely have been aware of the legal danger of dealing with an idea submitter and might not have listened to Desny at all.

${ }^{45} 46$ Cal.2d at 755-56, 299 P.2d at 280-8x.

"Ibid. It is to be hoped that he meant "literary work" literally. It is not at all clear when the statement is read in its context that he did. He may very well have meant "ideas."

${ }^{4298}$ P.2d 626, 628 (Cal. App.2d 1956). 
do so." No further correspondence and no meeting took place. In I953, or 1954, defendant began to sell a Betty Crocker Junior Baking Kit. The plaintiffs sued, alleging their idea had been embodied in the defendant's kit and their original format used. Demurrers were sustained to their several complaints. The circuit court affirmed, holding the complaint to be defective. With respect to express contract, the court said that even if the plaintiffs' letter could be construed as an offer, the offer had never been accepted. The plaintiffs' allegation that the use by General Mills constituted an acceptance was refuted by their own admission in their opening brief, wherein they said that General Mills "evinced great interest in the kit," but informed them that "they could not use it at that time." It also was refuted by the fact that the offer was not accepted within a reasonable time.

The court held the complaint defective with respect to implied contract, even though the conclusory allegation that the submission was made at the request of the defendant was present in this complaint, as it had been in the Weitzenkorn and Kurlan complaints, which had been upheld and on which the plaintiffs here relied. In this case, the letter itself contradicted the conclusory allegation, and the judges were not fooled.

In Thompson v. California Brewing Co., ${ }^{48}$ the plaintiff sought to recover for his alleged submission, at defendant's special request, of an allegedly novel idea to promote the defendant's beer sales-the idea being that defendant "should advertise and sell at least two kinds of beer under two different labels, including 'a man's beer,' and the then present beer under its then new label for the feminine and home consumption trade." Causes of action for express and implied contracts and for breach of confidence were upheld. This case is interesting for the fact that plaintiff's attorney attached importance to "novelty," despite the California Supreme Court decisions.

So much for California. Let us now get back East and see what happens when the submittees are another type of idea user-the President and Fellows of Harvard College. In Irizarry $v$. President and Fellows of Harvard College, ${ }^{49}$ the plaintiff alleged in counts one and four of the complaint that a series of reports on foreign tax systems which the Harvard Law School is preparing makes use of an idea which the plaintiff owned exclusively and which the defendants stole after the plaintiff had revealed it to Dean Erwin Griswold in 1950. Counts two and three allege that Griswold deceived Irizarry into disclosing his plans for a tax service. It may be observed at the outset that the plaintiff acted as his own counsel.

All contact between the two men was by mail. Irizarry had written Griswold asking him to look over the text of a loose-leaf service on Argentine tax law which he had prepared and which he planned to follow with similar services on other Latin-American countries. He stated they were to be along the lines of United States Tax Services published by Prentice-Hall and Commerce Clearing House.

40 No. 17137, Cal. Dist. Ct. of App. Ist Dist., April 26, 1957.

1D 248 F.2d 799 (Ist Cir. 1957). 
Griswold replied that he was interested; and some correspondence followed having to do with Griswold's participation, until Griswold said he did not care to pursue the matter further. Harvard Law School, in cooperation with the United Nations, is engaged in the publication of a series of reports on the tax systems of countries throughout the world. The first two of these reports were published in 1957, while Irizarry's Argentine service was published in 1951.

The defendants' motion for summary judgment was granted in the District Court by Chief Judge Sweeney, who held that there was no issue of fact; that the idea of a foreign tax service, not being novel, cannot be property; and that no promise to pay for the use of the idea can be implied if novelty and originality are absent. $^{50}$ On appeal, the Circuit Court affirmed, saying that, while the ground given below was sufficient, two other grounds also support the judgment-the first being that an unconditional public disclosure of an idea by the originator deprives him of any further rights in it. (In his first letter to Griswold the plantiff had said he had already disclosed his idea to 1500 important business and banking institutions and law firms throughout the country.) Moreover, the court held it perfectly clear that no implied contractual or fiduciary relationship had arisen between the parties, for ${ }^{51}$

the plaintiff's initial letter to Griswold, which was wholly unsolicited, disclosed and described the plaintiffts entire idea. All that Griswold ever requested from the plaintiff was further information as to the part Irizarry wished him to take and the financial arrangements which Irizarry proposed. Such a gratuitous unsolicited disclosure as the plaintiff made to Griswold could not impose upon the defendants a contractual or fiduciary relationship. Gromback [sic] Productions v. Waring, 1944, 293 N.Y. 609, 59 N.E.2d 425; Laughin Filter Corp. v. Bird Machine Co., 1946, 319 Mass. 287, 65 N.E.2d 545, 69 USPQ 23.

It is interesting to speculate on what the California Supreme Court might have done with this case had it been before it and had there been no prior disclosure to the 1500 firms. Obviously, the lack of novelty would not defeat Irizarry, and the possibilities in Griswold's request for further information about his part and about the financial arrangements proposed might very well have led to a different resultor possibly to a new rule in California. ${ }^{52}$

\section{III}

\section{Area of Submitter's Protection}

Just as the whole is greater than any of its parts, so the idea must be more comprehensive than any' single representation of it. Moby Dick is a titanic novel about a whaling voyage. Melville's copyright protection, if he wrote it today, on the basis of well-settled law, would not include the "idea" of it or the ideas in it."

Es Recall that in Desny the California Supreme Court held a submittee's promise following disclosure would be enforced.

${ }^{6 s}$ Nichols v. Universal Pictures Corp., 45 F.2d Iíg (2d Cir. 1930); Holmes' v. Hurst, I74 U.S. 82 (1899).
} 
The copyright protection granted him would not seriously discommode other authors or producers who wish to write or produce works about whaling voyages. Yet, if our present-day Melville, instead of honestly laboring for years to produce his literary masterpiece, conceived his idea about a whaling voyage, a hell-driven captain, and a white whale, wrote down the idea of it, and did little more than get potential users to listen to him rather than rudely shut him up, he would find himself in a position, were he dealing with men of no more than ordinary courage, to prevent them all from perhaps ever again doing any story dealing with these same elements. ${ }^{54}$ Contrast the labor the two Melvilles have done, and compare what each receives. The modern Melville-as contrasted with the real one-has not even begun to work. The literary output (if it can be called that) of the idea man would be quantitatively prodigious compared to that of the poor drudge. Are we sure we want to give the "hot idea" man all this power and encourage the Melvilles all to be "hot idea" men?

To say that he does not get much power, as did Judge Traynor in Stanley $v$. $C B S$, and that copyright protection creates a kind of monopoly and is, therefore, to be closely confined, while contract operates only between the parties, is no answer -at least in the field of broadcasting. There are only three national television networks in the United States. If the idea can be planted with all three, the possibilities are obvious; and they have been availed of. Although a vast area of broadcast material is produced outside of the networks, the submitter in such a case customarily sues both the outside packager and the network and alleges that the latter supplied the idea wrongfully to the former. Thus, the would-be idea monopolizer gets his chance at the big money no matter where the idea of the broadcast actually originated. Where it actually did originate does not worry him much; the proof of the idea's independent origination is by its nature almost never backed by "hard" evidence, but only by that of the self-serving variety. If the idea man is patient, something enough like it will come along in time. He can then make his claim, tell his story, and who knows?

Not only is his original task much easier than that of the drudge Melville; his task at the trial of his action is much easier than that of the network that he sues. The network program goes on the air as the result of the combined efforts of many people. The "hot idea" man can put in his whole case himself. Generally, this takes little time, although even this is many times what it typically takes to conceive and formulate the "hot idea." The network's evidence is costly to present, its witnesses difficult to assemble. The "hot idea" man has advantages all along the line over a real author who took the trouble to finish his work and secure Constitution-derived copyright protection for it.

The "idea" man runs no danger of having to pay an attorney's fee for the sub-

ss What would be the same idea? Would a whaling voyage, a hell-driven captain, and a black whale be the same? The captain and the whale, but no voyage? The voyage and the whale, but no captain? 
mittee who is victorious in a lawsuit. Not so the author who sues on his federal copyright. $^{55}$ Moreover, for a publisher of books, more areas are practically available for his use than for the broadcaster. The broadcasting industry-like Hollywood, but unlike publishers-is, by its present economic nature, forced to aim at a mass public. The broadcaster is further limited by the fact that his product goes directly into the home; material fit only for a limited class is not usable by him. Consequently, "idea-fencing" is more damaging to him than it would be to the publisher. Yet, the publisher is usually not a defendant in similar cases and is forbidden only those areas protected by valid copyrights, rather than comparatively vast idea areas. Theoretically, there is no reason, of course, why a publisher cannot be sued. Had Desny submitted his sixty-five page "composition" to a book publisher in California (or, it must be added, to the publisher's secretary), there is nothing in the Desny opinion to make one suppose that the publisher would be any more likely than Wilder et al. to succeed in having the complaint held insufficient if, after submismission of the manuscript, he had published another book dealing with the Floyd Collins tragedy. If the only question were whether the publisher had used copyright-protected portions of the work, there would be no objection. But that apparently is not the only question in California. Thus, the hobbling effect of the Desny doctrine, even on literature, is obvious.

Rewarding the idea submitter has the cultural effect of discouraging his doing useful work in the field of writing if he has talent for it or in the field of production if he has talent and has or can get the means to produce. The rewards given by juries have sometimes been very high. ${ }^{56}$ When the amount of effort and talent necessary to jot the ideas down on a few pages are considered, the rewards are sometimes shockingly large.

Assuming that a submission has been made which gives rise to obligations on the part of the submittee, to what area are the obligations confined? This question is one of paramount importance because invariably what is used differs to some extent from what was submitted.

Suppose, too, that the submission itself was a very general one. More uses will then fit into the suggestion than would be the case if the submission were narrow. The "value" of a general idea is, of course, much greater than that of a specific one,

${ }^{6} 61$ STAT. 652 (1947), 17 U.S.C. $\$ 201$ (1952).

${ }^{80}$ In Morgan v. General Foods (Cal. Super. Ct. I952), the jury originally returned a verdict for $\$ 750,000$ but was sent back after being advised that the punitive damage plea had been withdrawn and returned a verdict for $\$ 375,000$. In the Stanley case, the verdict was for $\$ 35,000$; in the Belt case, it was for $\$ 3,300$; in the Matarese case, it was for $\$ 40,000$; and in the Golding case, it was for $\$ 25,000$. The trend in this area is for money damages to vary inversely with the ascertainability of the injury suffered by the plaintiff or the value of the appropriated idea. Normally, damages are governed by the gauge of the market place, but since there is no market place for ideas-only for their various usable embodiments-the jury is free to speculate to its heart's content, confused by wild demands for tremendous sums. Honest jurymen who have never earned more than $\$ 6,000$ a year for their honest and useful labors are persuaded to return verdicts for tens of thousands of dollars for the appropriation of ideas which took matters of minutes to conceive. It might well be said, to paraphrase the splendid Churchill, that "never have so many who gave so little been rewarded so well." 
and the tendency of the submitter is to wrap up as much as possible of the idea: area in which he operates. A favorite device of the submitter is to make his suggestion and add "etc." at the end of it or a phrase like "there are many other variations which can easily be imagined." The result, of course, is to throw the submittee back onto his own resources-where he was before he got assistance from the submitter. In the light of the usual quality of work submitted, probably this is all: to the good artistically.

Aside from the question of degree of specificity, we have the case where some of the elements of the submission were used, but others were not. The problems in this area permeate every idea submission controversy. In none of the cases, to the writer's knowledge, has the court adequately discussed the problem. The reason: may be its difficulty!

Shall the submitter be protected with respect to the specific ideas falling within: the area of his general submission? If he should recover at all, should he recover if only part of his idea is used, or does the entire idea have to be used for him to. recover? If what is used is more general than the specific idea, is the defendant: liable? Suppose he suggests that a series of plays, after closing on Broadway, be performed on television in two-hour length. If the defendant performs in two-hour length a series of George $M$. Cohan plays which had Broadway runs, should the plaintiff recover? If the plaintiff suggests the George $M$. Cohan series, should herecover if the defendant uses everything but George $M$. Cohan plays? Suppose the programs broadcast utilize the idea suggested only as to one segment of the program. Out of two segments? Out of three segments? Suppose a submitter submits a vast amount of ideas. The writer on one occasion jotted down, in the period of a single hour and in spite of interruptions, twelve ideas for programs, noneof which he had ever seen before. By devoting himself exclusively to this unholy work, he is confident he could send forth a steady stream of these things and suein some cases, perhaps, successfully-any network or programmer unfortunate enough to receive the submission.

How are the legal rights of the parties affected by the fact that the idea submission, either wholly or partly, is in the form of matter which has been registered: for copyright in the Copyright Office? If the work was published with notice, have the ideas incorporated in it been publicly disclosed so that no idea protection is possible? Suppose the copyright material is accompanied by a letter pointing out that it could serve as the basis of a series of similar works. Is it possible to protect that idea? If the registered work were unpublished, would the registration itself constitute public disclosure? With how many people may the idea submitter enter into confidential relationships? Suppose he confidentially reveals his idea to several thousand submittees; is it still not publicly disclosed? Suppose thesesubmittees constitute the entire group of those who, as a practical matter, can use the idea? Suppose the group of submittees is made up of only three networks and? 
the suggestion envisages a series of ninety-minute programs, which only the networks at the present time regularly originate?

A child, the psychologist tells us, is born into the world with only a few ideas, including very little more than the tendency to grasp and to fear loud noises or great heights. Everything else is learned. In the early years, a prime method of learning-indeed, one might say the only method-is by imitation. The child benefits by the experience of our contemporary ancestors, who in turn leaned on preceding generations. A man becomes civilized, therefore, by acquiring and adopting ideas without permission. How many have ever during their lives paid for these ideas? Admittedly, we pay to be exposed to them by specialists-our teachers. But this is something else. We pay and employ teachers to communicate ideas and, generally, not for the ideas they communicate, at least not for their own ideas that they communicate. A teacher might be very acceptable who in his whole life never had an original idea, not to mention a novel one. What we pay for is chiefly an idea communicator rather than an idea originator. The idea submitter, having come into the world practically devoid of ideas and having, like the rest of us, freely appropriated all or almost all he knows, proceeds zealously to try to extract from others payments for the ideas which he believes he originates. Normally, the ideas he expects payment for are the cute, gimmicky, least important ideas in his life. If he has a set of ideas on why we should or should not go to war, he expects no one to pay him for communicating these, or for their use. If he has ideas on how to give away money prizes or how to subject program participants to amusing experiences, he hopes for a fabulous award. When an idea submitter is really good, society is badly misguided to encourage him to strive in the wrong area. Better to reward him if he civilizes the Soviets rather than if he amuses the Americans.

Every development in this area is not grave. Not too long ago, I received the complaint of a man who alleged his idea was incorporated into one of our programs. It developed that he had submitted it to a movie usherette in a New York theater operated by one of the theater chains. (If Desny $v$. Wilder had been decided at that time, perhaps I should have worried more.) Also the lady who suggested that her recent conversations with Mark Twain be broadcast on radio need have very little fear of this idea's being appropriated.

\section{IV}

\section{SOME Statistics}

Robert W. Sarnoff, president of National Broadcasting Company, recently said: "In the year now ending, NBC headquarter's, its stations, its field offices, its artists, and its producers will have received some three million letters from the viewing public. In New York alone, we will have had more than 4r,000 telephone calls praising or criticising our shows, and more than roo,000 telegrams." Dore Schary, one of the motion picture industry's outstanding producers, told recently on a tele:-

${ }^{57}$ Thirtieth Anniversary Address, Dec. 13 , 1956. 
vision program that a large studio receives 20,000 stories or ideas a year, of which but twenty are made into motion pictures. ${ }^{58}$

Of the three national TV networks, one, NBC, currently is receiving 30,000 to 40,000 . suggestions of all types every year. These figures include everything from letter outlines to pilot films. One department alone received from 7,000 to I0,000 "approaches" a year. From 2,000 to 3,000 get some serious study. Ten thousand story submissions of all types are offered. The effect of this tremendous influx is obvious. At the present time, the idea-submission lawsuits confronting the networks probably account for sixty-five per cent of all suits against them in the area of copyright, defamation, right of privacy, and unfair competition.

The extraordinary and multiple claims that result from idea protection are perhaps illustrated best by citing a case of a new program coming on the air and what happened to the network-NBC in this case-that put it on:

On March I, I954 the program "Home" was first presented on the NBC Television Network. Prior to its date of first broadcast, NBC had received six idea submissions claims relating thereto. The six claims were entirely independent of one another, and each claimant claimed that his idea submission would form the basis of the series to be broadcast. Advance publicity about the program, the only information probably available on which each of the claims could have been based, said little more than that "Home" would be a service-type (as opposed to entertainment-type) program, like a magazine-of-the-air. But this was not the end of our trouble, for following the first broadcast of the program three more claims came in. Two of them became lawsuits. The program went off the air following its broadcast on August 9, 1957 . Two of the three idea submission lawsuits concerning it are still pending. As late as July 3I, I957, a motion was noticed for an order enjoining the series three days prior to its going off the air.

The fact that the idea was old was no deterrent to the claims made regarding the "Home" program. A brief search of the exhaustive files maintained by NBC revealed that the network had received submissions of the basic "home" idea since x 929 -prior to the earliest of the nine claimants' alleged submissions.

On another program just put on the air, NBC has received a half-dozen claims and two lawsuits, one seeking a preliminary injunction. The foregoing experience is by no means isolated or extreme. Not many years ago, a new CBS program was the subject of no less than eighty-five claims, which resulted in seven lawsuits. The effect of these lawsuits and claims on a timid broadcaster is obvious. Such a broadcaster would tend to keep on the beaten track. Fortunately, however, to my personal knowledge, it has not had this effect on NBC or the other networks.

\section{V}

Present Handling of the Problem

The following is the idea-submission form currently in use by NBC in New York.

\footnotetext{
"Open Hearing, ABC-TV Network, Oct. 6, I957.
} 
NBC POLICY CONCERNING SUBMISSION OF IDEAS AND OTHER MATERIAL

We appreciate the courtesy of our listeners and professional people who suggest mate.rial, including ideas, program formats, literary material, and other suggestions, for our use. However, we receive many suggestions which have been made previously either by - our own staff or by others. Likewise, we may commence using material similar to yours which we receive after the date of your submission. It has therefore become necessary for us to adopt the policy of refusing to consider any material unless the person submitting it has signed the agreement appended to this statement and has specified the maximum payment to be made to him in the event of our use of his material. KINDLY DO NOT .SUBMIT TO US ANY MATERIAL WHICH YOU DEEM TO HAVE A VALUE IN EXCESS OF THE LIMITS SPECIFIED IN PARAGRAPH I OF THE BELOW AGREEMENT BETWEEN US. There are two copies of this agreement; please sign in the space provided and return one copy to us.

National Broadcasting Company, Inc. Title(s) $\ldots \ldots \ldots \ldots \ldots \ldots \ldots \ldots \ldots \ldots$ 30 Rockefeller Plaza

New York 20, N.Y. Attention: Story Division

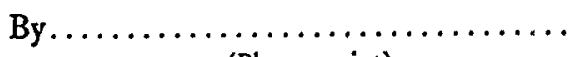
(Please print)

Gentlemen:

In accordance with your NBC POLICY CONCERNING SUBMISSION OF IDEAS AND OTHER MATERIAL, I am today submitting to you my material summarized on the reverse side pursuant to the following agreement:

r. You agree to cause your appropriate employee having the duty of evaluating material of the type now being submitted by me to review my material. I agree that you may use my material or one or more of its features or components. If you commence such use, and provided it is original, novel and valuable, you agree to pay me as total compensation therefor such sum of money as we may subsequently agree upon in writing. If we have not attempted or are unable to agree upon the amount of such payment and you commence the use of such material, you will pay and I will accept as full consideration for all rights of every kind, the sum of $\$ r, 000.00$ if the material is first used as the basis of a series of network broadcasting programs, $\$ 500.00$ if the material is first used as the basis of a series of local programs, or $\$ 250.00$ if the material is first used for any other purpose. I agree that I can suffer no damages in excess of the foregoing from your use of my material or for any other claim with respect thereto.

2. I declare that all of the important features of my material are summarized on the back of this form and I have disclosed no other features to you. I warrant that the material is original with me and that no one else to my knowledge has any right to it. I believe my material and its features to be unique and novel. However, I recognize that other persons including your own employees may have submitted to you or to others, or made public, or may hereafter originate and submit, or make public, similar or identical material which you may have the right to use, and I understand that I will not be entitled to any compensation because of your use of such other similar or identical material.

3. Any controversy arising as to whether you used my material, or relating to this agreement, will be conclusively determined by arbitration as provided by New York .law and the regulations of the American Arbitration Association and our arbitrator will be a person experienced in the broadcasting field mutually selected by us; if we cannot agree, we will accept as arbitrator any person designed by the President of the Association of the 
Bar of the City of New York who will agree to arbitrate the controversy, in accordance with the rules of the American Arbitration Association. The arbitrator's decision shall be controlled by the terms of this agreement and no award may exceed the appropriate amount specified in Paragraph I. I agree that any action against you must be brought within six months after the date of your first use of my material.

4. I have retained a copy of my material submitted to you and release you from liability for, loss of or damage to such material.

5. This agreement constitutes our entire understanding. Any modification or waiver hereunder must be in writing, signed by both of us. The invalidity of any provisions hereof is not to affect the remaining provisions. This agreement applies equally to any other material which I may submit to you, unless agreed in writing to the contrary.

(Author or Agent: Write on the back of this form a short summary of the contents of the material being submitted.)

Dated:

Name.

(Signature)

AGREED:

Address

(Signature)

National Broadcasting Company, Inc.

By

From time to time, this form is revised, and it is now in the revision process again. An earlier Davis v. General Foods Corp., ${ }^{59}$ type form follows:

The Company deeply appreciates the courtesy of many of its listeners and of people in the profession who submit ideas, suggestions and material for use in its activities. However, so many ideas and suggestions are offered to us which embody suggestions previously developed by members of our own staff, or submitted by others, that we cannot consider any material unless we receive a waiver of compensation therefor. Only in this way can we avoid the risks and uncertainties which often arise by reason of the use of ideas independently conceived and submitted to the Company by others.

Therefore, before considering any ideas, suggestions or material, it is the policy of the Company to require the signature of the release appended to this statment.

Title(s)

By

(Please print)

Date:

Gentlemen:

I have received a copy of your policy in connection with the submission of ideas and suggestions to you. I understand that it is your established policy not to entertain or receive an idea or suggestion except on the distinct understanding that the person submitting the same is willing to rely entirely upon your good faith in determining the question of whether the submission is truly novel, whether it is actually used by you as a result

${ }^{01} 2$ F. Supp. 445 (S.D.N.Y. 1937). 
of his having submitted it, and the amount of compensation, if any, to be paid if you should use it.

As an inducement to you to entertain my ideas and suggestions, I agree that they are submitted to you upon the conditions set forth above.

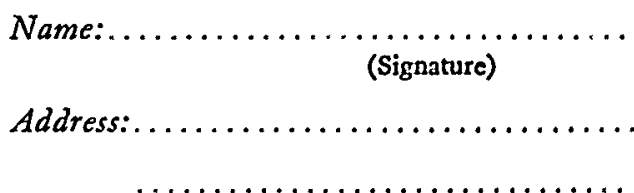

Witness: (Author or agent: Please write on the back of this form a short summary of the contents of the material being submitted.)

The Davis-type form is in wide use by firms in this country, and the cases support the view that the forms are useful in performing their functions. ${ }^{60}$

Each of the radio and television networks has its own way of handling the problem posed by unsolicited idea submissions. Letters of rejection are especially difficult to write. Some unfortunate stock phrases that creep into them are:

r. While we found it a very interesting idea for a program, we do not require any programming of this sort for the coming year.

2. The fact we cannot accept your idea at the present time does not mean it is not meritorious.

3. We are very grateful to you for allowing us to consider your idea, and we shall keep it carefully in mind for future programming.

Obviously, from a legal point of view, it is better to be blunt and have it done. A friend suggests that the following, where public relations will allow it, would be highly desirable in every case:

We have the idea which you sent us but have no obligation to you for it. We do not need ideas; we have so many ourselves that we are unable to work on due to lack of time that we venture to suggest that you develop a program rather than fool around with an idea. We can use programs. The custom in the business is to make a pilot film so that you have something concrete to show around. The cost of this may be $\$ 30,000$, but we assume that your friends and/or banker will be happy to back you if you yourself are unwilling or unable to finance it.

Copyright the film you make for your own protection. You will then "own" something. As it is, you have offered to sell us something you do not own, and we have no interest whatsoever in buying it.

Thanks anyway.

Users are not the only people who have forms. Some submitters do too. One man in the Midwest sent NBC a form as a preliminary to submitting his idea. A paragraph from the form follows:

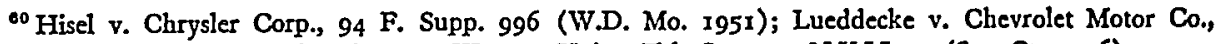
70 F.2d 345 (8th Cir. 1934); Rieger v. Western Union Tel. Co., 135 N.Y.J.L. 5 (Sup Ct. 1956). 
We readily acknowledge, that to study your format would contain much very valuable information and make possible to manipulate, fake, juggle, etc., and that neither we or any members \& employees associated with our organization would challenge to infringe on any portion of this program in ideas, titles, material and other information, when format submitted and made available for our study, to do so, would constitute a violation of your trust in our agreement as well as making us and our organization, liable in restitutions as may be imposed upon us. (sic)

This is fine. At least the submittee knows where he stands when he accepts an idea from this man.

VI

\section{SUGgESTED LEGISLATION}

In Kurlan v. Columbia Broadcasting System, the defendants argued that the complaint showed the alleged contract to be within the bar of the statute of frauds. The court expressed doubt that the transaction alleged might be a sale of "goods" within section $1624 \mathrm{~A}$ of the California Civil Code but held that in any case, the transaction would be removed from the operation of the statute by acceptance of part of the goods; and, if Kurlan's allegations about access, copying, and use were upheld, acceptance of at least a portion of the goods would be proved and so the statute would not bar the action. Perhaps the court's position was conceptually correct; but how strikıng the need for inclusion of such transactions within the bar of the statute! If there be a need for the statute in the field of the sale of tangible goods, who can doubt a more pressing need in the case of a sale of an idea? In Weitzenkorn, the majority said that, though improbable, if the defendant allegedly promised to pay for the disclosure of a hackneyed idea, a contract valid in law would exist upon proof that such a promise had been made. It seems that the improbability coupled with the obvious opportunity for fraud makes evident the desirability of inclusion of this sort of action in the statute of frauds bar.

\section{VII}

\section{Several Frnal Observations and Questions}

The courts have said on occasion that a man's right to his ideas is analogous to a wild animal he has captured. If the animal escapes, he loses his right to it; likewise if he allows the idea to escape he loses his right in it. By "his ideas," I assume the courts do not really mean the idea taken alone. They must have reference to the idea as it exists in the man. No court has ever meant that the man who has not permitted the idea to escape him could prevent others with the same idea from using it. It would be odd to consider as separate ideas the same idea existing in the minds of two people. The fact that we use the language "same idea" means the two conceptions are really one. But, letting that pass, the courts have held that on disclosure, the idea belongs to the world and, unlike the wild animal, cannot be captured again and be owned by the captor.

What kind of disclosure results in the escape of the idea? It is clear that a 
confidential disclosure does not. Following a nonconfidential disclosure does the discloser lose his rights to the one to whom he earlier disclosed confidentially? Of course, he should. The rest of the world is now free to use the idea. The discloser has robbed the initial disclosee of any practical exclusivity he might have had from being the recipient of the disclosure. Consequently, the discloser should not continue to benefit after he has destroyed the advantage of the disclosee.

Suppose the disclosure is not voluntary. Here, consider the situation of a discloser who, in the process of suing a confidential disclosee, has to reveal what the idea was which was disclosed. To go a step back, does the disclosure by the user in breach of any express or implied obligation result in a loss by the originator of "his idea"? It is submitted that it should. The public is in no position to know the circumstances under which an idea was disclosed and to trace origins where there are no earmarks. In the modern world, there is little enough time for human genealogy without attempting idea genealogy.

The tendency since International News Service v. Associated Press to find that there is property merely because someone has used it before, "even if it took labor and genius to make it," is untenable, as Justice Holmes pointed out. Property depends upon exclusion by law from interference, and if it is to be created, it is for the legislature to do it, not the courts. ${ }^{61}$ The question is whether we shall allow someone to appropriate to himself, by whatever means, that which belongs to everyone, and not whether someone has labored mightily.

The basic reason, of course, that copyright law has tended to protect only the specific matter written down, rather than the general ideas incorporated in the work, is that there are infinitely more combinations of individual words than there are ideas or, indeed, combinations of ideas. To fence off ideas and combinations thereof, as opposed to words, would place restrictions on the world's artists to a much larger extent than the inconsequential contribution of the world's submitters warrants.

The evil of permitting recovery to the idea submitter, other than in an express written contract situation, is threefold. It encourages men to waste their time dreaming up ideas in areas where they lack the experience to know what is needed or useless, practical or not, new or known. Secondly, it encourages fraud. Thirdly, it discourages the use of new ideas. The discouragement of such use is not limited to those areas where new ideas have been submitted by outsiders; it is more general than that. Even an individual cannot possibly remember the source of his ideas. For a corporation of any size, the problem of determining an idea's source is simply stupendous and incapable of practical solution.

The principal effect of allowing recovery on implied contract, quasi-contract, and on certain other theories is sometimes to give idea protection against a narrow circle of people, but sometimes, for all practical purposes, to give protection against everybody who might use the idea. This is in direct opposition to the well-settled

${ }^{62} 248$ U.S. 215 , at 246 . 
principle of the law that ideas should be free, since they are the tools of society. As Augustine Birrell said, ${ }^{62}$

Ideas, it has always been admitted, even by the Stationers' Company, are free as air. If you happen to have any, you fling them into the common stock, and ought to be well content to see your poorer brethren thriving upon them. He and he alone is the really great and fortunate author whose books mark epochs in the history of thought, so that you may confidently assert of any work that it was written before or after the appearance of these memorable productions. This is indeed to live up to the parliamentary preamble, and to write books "of lasting benefit to the world." And how does the world benefit if not by appropriation and by assimilation.

Of many idea submitters, the same thing might be said that Birrell said of certain scribblers: ${ }^{63}$

The utmost I am willing to admit against the Society of Authors is that the editor of its monthly paper, "The Author," occasionally admits into its correspondence-columns the most truly amazing letters from persons engaged in the ancient craft of scribbling, which argue an inflated belief in the value and importance of literary compositions which can only entail disappointment, misery, and even madness upon its most unhappy victims. To encourage these poor nympholepts in their vain pursuit of editors and publishers is sheer barbarity.

What is this evil anyway that some of the judges strain so hard to correct? All men have the tendency to copy and adapt ideas; if they did not, we would never have gotten far. Written contract and copyright are valid areas of protection, but otherwise, generally, there is no moral evil to be guarded against. Indeed, the trait is not confined to the human race; and the copying of ideas cannot be too evil, for, as the elder Dumas said, God created man but even He could not avoid the use of a Prototype. ${ }^{84}$

- Augustine Birrele, The Law and History of Copyrigets in Books y67-68 (r899).

${ }^{82}$ Id. at 204.

'idea stolen from Alexander Lindey, Plagiarism and Originality 280 (1952). 